\title{
Тарас Лютий
}

\section{ФІЛОСОФСЬКИЙ ПЕРФОРМАНС СЕРГІЯ КРИМСЬКОГО.}

\section{Кримський, С. (2019). Вибрані твори у 4 книгах. (Т. Лютий, Ред.). Київ: Альфа-ПІК.}

Серед тих, хто особисто був знайомий із Сергієм Кримським, або бодай раз відвідав його лекції, думаю, небагато хто залишився цілком байдужим і щодо тематики цих промов, і стосовно самого їх видовища. Особисто я схильний вважати, що живі виступи Кримського нагадували те, що можна назвати філософським перформансом. Цим словосполученням окреслюється не просто певна риторична спроможність, уміння вибудувати захопливий наратив і демонстрація високого рівня обізнаності 3 філософським матеріалом. Ідеться, здебільшого, про особливий феномен життєвого втілення філософії, що супроводжується схопленням у слові істини буття. У Кримського всі ці характерні особливості поєднувалися з голосовими модуляціями, інтонаціями, жестами, ба навіть запикуватістю, які тільки увиразнювали сказане. Тепер, коли вже минуло десятиліття після відходу Кримського в засвіти, відчувається глибока прогалина, нестача практик подібного філософського театру. Тому приходить час відкривати тексти цього видатного філософа.

Думка про публікацію кількатомового видання творів Сергія Кримського вперше 3'явилася навіть не серед філософів, а в одного з керівників телеканалу СТБ і тепер уже колишнього міністра культури, молоді та спорту Володимира Бородянського. Колись, відвідавши лекції та прочитавши в пресі виступи українського мислителя, він був здивований тим, що про філософію можна говорити настільки витончено та доступно. Ці чинники й зумовили потребу оприлюднити не окремі фрагменти творчої спадщини Кримського, а видати якщо й не повне зібрання його творів, то для початку бодай найбільш значущі праці. Саме так виникла ідея наново опублікувати Кримського.

3 питаннями про можливість реалізації цього проєкту його ініціатори звернулися до відділу комунікації з випускниками НаУКМА, а вже звідти запит надійшов до кафедри філософії та релігієзнавства, де свого часу працював, зокрема, і Кримський. Я не тільки знав Сергія Борисовича і спілкувався з ним, але й писав під його керівництвом магістерську роботу. Ще трохи згодом він був опонентом моєї кандидатської дисертації, і на цьому наше спілкування не обірвалося. Тож мені було дуже приємно прийняти запрошення до такого проєкту. Робота почасти нагадувала дослідницьке за-

(C) Т. Лютий, 2020 
вдання, позаяк довелося не просто зібрати можливі електронні публікації, а й вирушити в бібліотеку Інституту філософії імені Григорія Сковороди, де зберігаються ще перші монографії Кримського. Деяким із них уже замінили зношені від старості палітурки, що свідчило про затребуваність цих видань протягом десятиліть. Отож, переді мною постало завдання придумати концепцію, відібрати твори, вибудувати логіку їх розташування, а потім уже братися за практичне втілення цього задуму. Доволі важливим критерієм відбору стала потреба репрезентативності текстів, які створювалися в певні періоди життя Кримського. Виникала необхідність докладніше заглибитися в біографію українського філософа. Допоміжними джерелами в цій підготовці стали передовсім два видання, здійснені колегами з Інституту філософії: біографічна нотатка з бібліографічного покажчика друкованих праць Сергія Кримського, створеного зусиллями Петра Йолона, і цикл інтерв’ю, які провела Тетяна Чайка. Саме ці свідчення й дозволили простежити трансформацію поглядів Кримського.

По тому розпочалася підготовка до відбору творів, їх сканування, вичитування та редагування. Мушу зізнатися, для мене одного такий обсяг завдань був би нездоланним. Величезну роботу з виконання технічної обробки цифрових масивів текстів допомогли зробити працівники «Лабораторії законодавчих ініціатив». Складність завдання зумовлювалася ще й тим, що при розробці концепції я ухвалив рішення не обмежуватися лише друкованими виданнями. Річ у тім, що залишилося чимало відеозаписів лекцій, телевізійних програм і публічних виступів Сергія Кримського. Деякі 3 цих матеріалів викладені на популярному відеохостингу YouTube. Я й сам колись записував аматорськими засобами одну з таких лекцій, прочитану в НаУКМА. Як виявилося, у приватних архівах десь існують навіть записи екскурсій Києвом, які регулярно проводив філософ. Можна лише уявити собі колосальний обсяг роботи з переведення викладених Кримським думок із аудіоформату в текстовий. I все це з урахуванням перформативної специфіки, про яку йшлося на початку. Оскільки в задумі видання поступово з'являлися тексти, сказати б, усної традиції викладання, такий собі сократичний варіант, планувалося, що перша книга мала містити, по-перше, біографічний нарис про життя філософа, адресований переважно тим, хто про нього або геть нічого не чув, або має лише поверхові знання; по-друге, тексти зафіксованих публічних виступів, численних інтерв'ю в пресі чи поданих у спеціальних виданнях, а також публікацій і статей, створених Кримським спеціально для довідкової літератури.

Щойно викладені міркування дозволили упорядити першу книгу видання під назвою «Лекції. Статті. Інтерв'ю». Передбачалося, що саме вона допоможе читачеві скласти загальне враження про філософію Кримського, ознайомити з його життєписом і лекційними виступами, публіцистичними працями, інтерв'ю та статтями в наукових і енциклопедичних виданнях. Наступні три книжки сформовані у вигляді збірок безпосередньо за тематикою досліджень, яку проводив Сергій Кримський протягом усього свого життя. Увесь творчий доробок філософа було поділено на три умовні періоди: логіко-методологічний, культурологічний, софійно-ноосферний.

Назва другої книжки «Логіка. Методологія. Наука» відповідає першому періодові й охоплює такі твори: «Генезис форм і законів мислення», 1962; «Научное знание и принципы его трансформации», 1974; «Логико-гносеологические условия постановки проблемы нового знания», 1983. Вони присвячені проблемам еволюції логічних форм і законів мислення, питанням історії мови, онтогенезу психіки, фізіології, антропології, етнографії, історії культури та кібернетики. Проблема знання розкривається філософом через логіко-гносеологічний аналіз тексту як логічної та мовної системи. Автор 
подає типологію знання, розглядає розвиток наукового мислення, вивчає проблеми інтерпретації та принципи побудови теорій.

Відповідно, третя книжка дістала назву «Пізнання. Духовність. Культура». Сюди ввійшли такі тексти: «О статусе понимания», 1986; «Типы и принципы рациональности», 1989; «Эпистемология культуры», 1993; «Новое мышление как философско-методологическая проблема», 1993; «Культурні архетипи Києва», 1997; «Діяльність і культура», 2003; «Пафос пошуку» (фрагмент з твору «Під сигнатурою Софії»), 2008; «Ранкові роздуми», 2009. У цих вибраних працях прослідковується перехід від логікометодологічних принципів пізнання до епістемології, утім, некласичного типу. Видно, як Кримський поступово пропонує узагальнену теорію пізнання, що передбачає принципи раціональності, розуміння й духовності, котрі стають людськими екзистенціалами, а загальнологічні чинники доповнюються соціокультурними.

Нарешті, матеріали четвертої книжки «Людина. Софійність. Історія» представлені текстами, які можна знайти у монографії «Під сигнатурою Софії» (2008). Задум автора полягав у дослідженні шляхів самотворення людини в контексті абстрактних і персональних категорій, як-от дух або доля, а також локальних і загальних, штибу національної цивілізації. Проте наскрізним орієнтиром філософ обирає концепцію софiйності, яку осмислює як принцип буттєвої мудрості, святості, урешті-решт, творчості. Тут знову спостерігаються характерні переходи: спершу аналізується проблема символіки пізнання чи наукового розвитку, от тільки їхня значущість постає як шанс виживання людини, а потім подається розуміння принципів духовності, без яких не збагнути, приміром, узагальненої раціональності. Не менш цікавими $є$ інтерпретації метаісторії та постісторії.

Саме таким чином і розподілилася тематика видання. Його наповнення відбувалося згідно з наведеним поділом. Варто зазначити, і це вже помітно з поданого раніше переліку праць, що велика частина включених до цього зібрання текстів написані російською мовою. Напевно, цілком очевидним було рішення не перекладати їх українською, щоби зберегти автентичність і своєрідність уживання слова Сергієм Кримським, який, принагідно зазначу, був білінгвічним у своєму філософуванні. Дещо варто пояснити і про праці, написані в радянський період. Для когось із наших молодших сучасників часті покликання на класиків марксизму-ленінізму в текстах, які увійшли здебільшого до другої і третьої книжок, можуть виглядати дещо невиправданими, чи то пак застарілими. Проте в тодішніх творах Кримського, як і у багатьох авторів того часу, подібні речі виглядають радше як «ритуал», якого годі було уникнути. Тоді без таких покликань не могло йтися про академічні публікації.

Декілька слів потрібно сказати і про лексику Сергія Кримського. Як і будь-який самобутній мислитель, він удавався до різного роду словотворів, у такий спосіб підкреслюючи експресію власної думки, що, знову ж, є ознакою задекларованого на початку філософського перформансу. Читач зможе сам належно оцінити гру смислів у звучанні термінів, які вдалося зафіксувати тільки побіжно, а серед них: «предметотворчість», «мислеформа», «всейність», «іншовираз», «самостояння», «вселюдина», «технодрама», «цілереалізація», «позасторонність» і багато інших. На перший погляд може також здатися дивним, що в деяких текстах перегукуються схожі сюжети, а радше приклади, на основі яких Кримський пояснює свої теоретичні настанови. Проте кожного разу видно, що ці повтори є ніби моментами постійного особистого переживання, що допомагають наново відтіняти сказане. Якщо їх вилучити, можна втратити живий ритм думки. 
Доводиться визнати, що оскільки це зібрання творів Сергія Кримського профінансоване приватними коштами, вийшло воно зовсім невеликим накладом - лише 100 примірників. На жаль, побачити його в книгарнях неможливо. Натомість почитати його можна в бібліотеках Інституту філософії чи в НаУКМА. Знайомство з рефлексіями Кримського найкраще починати з першої книжки цієї збірки. Нижче спробуємо подати деякі ключові точки його філософування саме на підставі цього матеріалу.

Передовсім філософію він визнає не більше, не менше як способом виживання. Таким чином, життя і філософія пов'язані між собою, позаяк життєвий учинок має відповідати осмисленій тезі. Філософія дозволяє уникати минущого й прилучатися до того, що є найбільш вагомим в історичному процесі й тим сприяє людському входженню в буття. Такими точками входження можна вважати архетипи - наскрізні структури, що пронизують історичне й культурне тло. Завдяки їм із життєвої одномірності можна вийти в багатомірність, подолавши найбільші випробування. Архетипи мають символічний характер і утворюють «структури прориву до вічності». Найпоширенішим архетипом української ментальності Кримський вважає слово. Тобто світ постає як книга, сповнена словами «святої правди», а часом навіть «зброї». Слово не тільки знак, який має обмежене коло значень, а символ, тобто ціла картина. Іншим архетипом визнається свобода, зрозуміла як гідність, або неможливість ухилитися від правди. А це означає, що філософія формує духовний рівень людини - заклик, який ще треба вміти розшифрувати, не обмежуватися лише природним рівнем буття, робити над собою зусилля, що ведуть до трансформації, отже, формування духовної особи, здатної постійно підноситися над собою. Це означає зовсім не нехтування матеріальним, а усвідомлення його глибокого зв'язку з духовним.

Важливо зрозуміти, що це не заклик зректися всього земного, сформувати йому сувору опозицію і протидіяти. Духовність стає горизонтом наших дій. Але щоб ідеї не мали здрібнілого й банального наповнення, якраз і потрібні людські духовні якості. Останні Кримський трактує як відразу до підлості, жорстокості, негідності, зла. Одне слово, життя має розглядатися не просто як витратний матеріал, який, урешті-решт, вичерпується, а радше як сила, що зростає до своєї кульмінації, стаючи екзистенційним вінцем. У цьому полягає ідея людського абсолюту. Хоча тут на людину чигають найбільші небезпеки. Наприклад, не піддатися фанатизму, самообманові, захланності, нетерпимості тощо. Для цього потрібна така ознака філософування, як раціональність, адже без неї не може бути жодної домірності. Але й раціональності ще замало. Вона може не виявити таку ознаку людини як суперечливість. А це під силу тільки мудрості. Найбільшою прикметою останньої є не посідання однозначно обгрунтованої позиції, а спроможність побачити рацію в думці Іншого, коли учасники діалогу раптом розуміють, що причетні до якогось спільного виміру, який становить для них спільну цінність. Його Кримський і називає «третьою правдою».

Шляхи, якими рухається людина, можуть бути різними. Такими є і методи пізнання світу, що складаються з послідовності дій відповідно до принципів чи ідеалів. Ясно, каже Кримський, що всякий метод має межі свого застосування, бо інакше неодмінно втрапиш у халепу, коли ідеали перетворюються на ідолів. Тоді спостерігаються зловживання редукціонізмом або надмірним символізмом тощо. Метод не веде до істини, наполягає філософ, із його допомогою вона може лише усвідомлюватися. Окрім того, один і той самий метод, залежно від контексту, часом приводить до різних висновків. 
Узагалі знання може нести згубу, якщо перетворити його на суто прагматичний інструмент. Тепер цікаво спостерігати, веде далі Кримський, як сучасна людина часто використовує знання заради досягнення якоїсь вузько специфікованої мети, приміром, винятково для кар'єрного зростання чи матеріальної вигоди. У таких випадках, культивуючи якийсь один бік справи, неодмінно нехтуватимеш іншими. Так, знання може перетворитися на проблему. Тому людським покликанням є не лише пізнання, але й освоєння світу. Через це, окрім філософії як знання, для людини важливим є і світогляд, себто сукупність орієнтирів (традицій, вірувань, прагнень). I тут впору знову повернутися до мудрості, котра є не здобуванням істини, а життям у ній. Якщо знання приводить нас у світ речей і фактів, то на рівні освоєння світу ми занурюємося у світ культури, коли речі ніби оживають. Це не бездушно-предметний світ, а одухотворений, а точніше наповнений смислом. Коли, наприклад, вода і вогонь розглядаються не як хімічні сполуки чи реакції, а як жива волога чи лагідне світло оселі. Такий світ людини Кримський називає ціннісно-смисловим універсумом. Тільки в цьому світі непомітні речі оприявнюються. Час стає не просто невидимою тривалістю, а осередком здійснення наших прагнень і сподівань, де ми перетворюємося на справжніх гравців.

У зв’язку з пізнанням і освоєнням світу Кримський пропонує розподіл на інтерпретацію й розуміння. Щойно в нашому пізнанні ми зустрічаємося з чимось незнайомим, як одразу ж нам потрібно його помістити в знайомий контекст, тобто створити ситуацію заволодіння інформацією. Перетворюючи один тип знання на інший, ми немовби рухаємося по горизонталі. Натомість розуміння пов'язане з прилученням до певного виду діяльності. Ми входимо в ситуацію, створюючи ії смисл. Подібні міркування наближають нас і до проблеми людини, позаяк остання не обмежується лише раціональними ознаками. Стверджуючи, що родових ознак у визначенні людського зовсім недостатньо, Кримський наполягає на потребі актуалізації особистісних характеристик. Людина є проєктом самостановлення, отже, здатна сама вибудовувати шлях до себе, шукаючи щось таке, як «внутрішня, духовна людина». Це пошук самокерованої особистості, процес творення якої триває впродовж усього життя. Тому однозначно схопити сутність людського ніколи не вдається. Крім того, на цьому шляху доводиться весь час боротися зі злом у собі, а в Іншому вчитися розпізнавати придатне до порятунку добро.

Цікаво, що у своїх міркуваннях Кримський знаходить місце для іронії. Бо не варто перетворювати філософування на ригористичну проповідь. Нав'язування власних думок виростає з невпевненості в собі. Тому людина весь час має справу з вибором, який здійснюється в просторі моральних координат. Утім, мораль як така буває доволі небезпечною, а отже, веде до парадоксів. Заглядаючи всередину себе та живучи на кордоні з Іншим, людина робить вибір. Мораль не наказ, а спосіб виживання у світі, протистояння звабі думати, що ти досконалий. Зло Кримський визначає як знепритомнення свободи. Можна сказати, що це відмова самостійно розважати, як належить чинити. Зло діє швидше, а тому добро завжди запізнюється, оскільки потребує розважливості.

Поряд із цим стоїть і здатність людини до порятунку себе і світу. А такий порятунок Кримський пов'язує з мистецтвом. У зверненні до всього зневаженого реальність ніби оживає. Мистецтво оберігає нас від неповноти, а водночас і розширює коло буття. Через це краса стає коротким, але непростим шляхом до досконалості. Здобутки цивілізації почасти роблять людину нечутливою до внутрішнього світу й призводять до торжества матеріального інтересу. Забезпечення має урівноважуватися закликами духовності, тобто ціннісної орієнтації особистості, покликом до внутрішнього 
самостояння. Цей шлях є найдовшим. До всього, для багатьох він зовсім не очевидний. А це спричиняється до дефіциту людських якостей.

Кримський наполягає, що новітні виклики вже не надаються до розв'язання в загальній формі, а потребують участі особистості. Типове зведення цивілізаційних процесів винятково до політичної діяльності, призводить до втрати культурного, а врешті, особистісного виміру. Така ситуація постійно обертається «аварією людських ілюзій».

Цими заувагами хочеться вкотре привернути увагу до творів Сергія Кримського. Важливо сприймати їх не як доктринальний дороговказ, а як підставу вступати в діалог, який дозволить реагувати на виклики сучасності й полемізувати 3 позиціями філософсько-перформативного мислення Кримського.

Одержано / Received 12.01.2020

\section{Taras Lyuty}

\section{Philosophical performance of Serhiy Kryms'kyi. Kryms'kyi, S. (2019). Selected} works in 4 books. (T. Lyuty, Ed.). Kyiv: Alpha-PIC.

Review of Kryms'kyi, S. (2019). Selected works in 4 books. Book. 1: Lectures. Articles. Interview; Book. 2: Logic. Methodology. Science; Book. 3: Knowledge. Spirituality. Culture; Book. 4: Man. Sophia. History. (T. Lyuty, Ed.). Kyiv: Alpha-PIC.

\section{Tарас Лютий}

Філософський перформанс Сергія Кримського. Кримський, С. (2019). Вибрані твори у 4 книгах. (Т. Лютий, Ред.). Київ: Альфа-ПІК.

Огляд видання Кримський, С. (2019). Вибрані твори у 4 книгах. Кн. 1: Лекиії. Статті. Інтерв'ю; Кн. 2: Логіка. Методологія. Наука; Кн. 3: Пізнання. Духовність. Культура; Кн. 4: Людина. Софійність. Історія. (Т. Лютий, Ред.). Київ: Альфа-ПІК.

Taras Lyuty, Doctor of sciences in philosophy, Professor of the Department of Philosophy and Religious studies of National university of Kyiv Mohyla academy.

Тарас Лютий, доктор філософських наук, професор кафедри філософії та релігієзнавства Національного університету «Києво-Могилянська академія».

e-mail: t.lyutyi@ukma.edu.ua 